\title{
PHOSPHORUS USE EFFICIENCY OF SOYBEAN CULTIVARS IN CERRADO CONDITIONS OF TOCANTINS, BRAZIL
}

\section{EFICIÊNCIA DO USO DE FÓSFORO DE CULTIVARES DE SOJA EM CONDIÇÕES DE CERRADO TOCANTINENSE}

\author{
Gustavo André COLOMBO ${ }^{[1, *]}$, Joenes Mucci PELÚZIO ${ }^{[1]}$, Luiz Paulo Miranda PIRES ${ }^{[2]}$, Douglas José \\ DARONCH ${ }^{[3]}$ e Gilberto Coutinho MACHADO FILHO ${ }^{[1]}$

\footnotetext{
[1] Universidade Federal do Tocantins, Programa de Pós-graduação em Produção Vegetal. Rua Badejós, S/N Zona Rural. CEP $77402-970$ - Gurupi, TO - Brasil.email joenesp@uft.edu.br e coutinhoagro@hotmail.com

[2] Universidade Federal de Lavras, campus Universitário - Caixa Postal 3037, Departamento de Agricultura. CEP 37200-000 - Lavras, MG - Brasil. email luizpaulo_vortex@hotmail.com

${ }^{[3]}$ Instituto Federal do Tocantins, campus avançado Formoso do Araguaia. Av. Joaquim Batista de Oliveira, S/N. CEP 77470-000 - Formoso do Araguaia, TO - Brasil. email douglasdaronch@hotmail.com
}

*Author for corresponding: colombo@uft.edu.br INFORMATION ABSTRACT

Received: 08/19/2015

Accepted: 02/26/2016

Published: 03/28/2016

Document Object Identifier

10.18067/jbfs.v3i1.53

Editor: V. H. G. Sales

jbfs@ifap.edu.br

ID JBFS2015053

Double blind peer review

Prot. $0532015 R 01$

Prot. 0532015R02

Copyright: (C) 2016

JBFS all rights (BY NC SA)
In order to determine the efficiency and response regarding the use of phosphorus of soybean cultivars, experiments were conducted in the 2013/2014 season, to evaluate 15 soybean genotypes under two phosphorus using a randomized complete block, with three replications. To simulate environments with low and high levels of phosphorus, doses of 40 and 120 kg.ha-1 of P2O5 were applied. Characteristics were evaluated for number of pods per plant, grain yield and using the methodology proposed by Fageria \& Kluthcouski (1980), determined efficiency in the use of phosphorus. The environment high phosphorus positively affected the average grain yield in all genotypes, with an increase of $48.9 \%$ over the average grain yield in low-phosphorus environment. Cultivars JULIANA RR, M9056 RR, P99R01 and M9144 RR were classified as efficient and responsive as the use of phosphorus.

Keywords: Glycine max, nutritional efficiency, mineral stress.

RESUMO - Com o objetivo de determinar a eficiência e resposta quanto ao uso de fósforo de cultivares de soja, foram conduzidos ensaios na safra 2013/2014, avaliando-se 15 genótipos de soja em duas condições de adubação fosfatada, utilizando um delineamento experimental em blocos casualizados, com três repetições. Para simular os ambientes com alto e baixo nível de fósforo, foram utilizadas, respectivamente, doses de 120 e $40 \mathrm{~kg} \mathrm{ha}^{-1}$ de $\mathrm{P}_{2} \mathrm{O}_{5}$. Foram avaliadas as características de número de vagens por planta, produção de grãos e, através da metodologia proposta por Fageria \& Kluthcouski (1980), determinada a eficiência no uso do fósforo. $\mathrm{O}$ ambiente de alto fósforo afetou positivamente as médias de produtividade de grãos em todos os genótipos, com um acréscimo de $48,9 \%$ em relação as médias de produção de grãos em ambiente de baixo fósforo. As cultivares JULIANA RR, M9056 RR, P99R01 e M9144 RR foram classificadas como eficientes e responsivos quanto ao uso do fósforo.

Palavras-chave: Glycine max, eficiência nutricional, estresse mineral.

Financiamento: Os autores reportam que não houve suporte e auxílio financeiro.

Conflito de interesse: Os autores declaram que não há conflito de interesse.

Como referir esse documento (ABNT):

COLOMBO, G.A.; PELUZIO, J.M.; PIRES, L.P.M.; DARONCH, D.J.; MACHADO FILHO, G.C. Phosphorus use efficiency of soybean cultivars in cerrado conditions of Tocantins, Brazil. Journal of Bioenergy and Food Science, Macapá, v.3, n.1, p.42-49, jan./mar., 2016. DOI:10.18067/jbfs.v3i1.53 


\section{INTRODUTION}

The Cerrado is the second biggest Brazilian biome, covering an area of 2.04 million ha, representing about $24 \%$ of the country. Since it presents geopolitical conditions favorable to the large-scale production, it comprises, nowadays, the main Brazilian agricultural region, responsible for $42 \%$ of the gross national production (GNP) of agribusiness ${ }^{1}$. Among the 96 million tons of soy produced in the $2012 / 2013 \mathrm{crop}, 67 \%$ are from the cultivation in Cerrado areas ${ }^{2}$. Prospects that global demand for the grain may reach 319 million tons in 2020 (growth of $23 \%$ compared to 2012) assign to Cerrado the role of main agricultural barn, and the responsibility of offering food to population in the coming decades ${ }^{3}$.

Due to climate characteristics, source material and high degree of weathering, the Cerrado soils, normally red-yellow colored and with good drainage, are intensely leached, with low natural fertility ${ }^{4}$. With particular chemical characteristics, they present conditions of high acidity, related to the presence of minerals low activity clay, and consequent adsorption of anions, mainly phosphorus. In these soils, the majority of phosphorus is in the form of non-labile $P$, being necessary to increase the fraction of phosphorus available for plants through the application of soluble mineral fertilizers ${ }^{5}$.

Phosphorus, as one of the macronutrients for plant development, performs important role in production, transference and energy storage via ATP and NADPH, in all biologic processes. It is central component of metabolic processes, including photosynthesis and respiration; participates of activation and deactivation of enzymes, beyond its structural function in the conformation of nucleic acids and phospholipids ${ }^{6}$.

The nutritional adjustment in soybean crops depends, beyond the technology level used, on the ability to uptake and use of phosphorus by plants, characteristic that is related to morphophysiologic parameters of genetic orientation specific of each cultivar, and expressed in function of environmental conditions in the cultivation area$^{7}$. The utilization of efficient cultivars in phosphorus use is considered an important strategy to reduce the production cost of agricultural species.

The literature proposes several specific methodologies for mineral stress, applicable to plant breeding in the selection of efficient genotypes regarding the use of the nutrients and efficient genotypes responsive to the nutrients application $^{8-10}$. Fageria e Kluthcouski ${ }^{8}$ define the efficiency in the nutrient use as the average of the grain productivity in low level nutrient, being the response to its utilization obtained by the difference between grain productivity in both nutrient levels, divided by the difference between the doses. Recent studies prove the effectiveness of the methodology of Fageria e Kluthcouski ${ }^{8}$ in the determination of efficiency in phosphorus utilization in genotypes of rice, bean and corn ${ }^{11-13}$.

The discrimination of soybean cultivars regarding the efficiency in use and response to the use of phosphorus fertilization, besides favoring the correct agricultural planning and the productive sustainability, generates subsidies to breeding programs focused on the achievement of superior cultivars in Cerrado areas, since they classify and select potential parents to form segregating populations.

Thus, this study aimed to determine the efficiency and response regarding the phosphorus use of soybean cultivars in conditions of southern Cerrado of Tocantins, Brazil.

\section{MATERIAL AND METHODS}

The experiments of high and low phosphorus (P) levels were performed in the experimental station of Universidade Federal do Tocantins (Federal University of Tocantins), in municipality Gurupi - TO, located at 280m height, 11ㅇ' $48^{\prime \prime} \mathrm{S}$ latitude and 49.03'12" W longitude, in the agricultural year of 2013/2014.

For the study, 15 soybean cultivars were used (P98Y51; P98Y70; P99R01; P99R03; P98R91; JULIANA RR; STS 820 RR; M9056 RR; M9144 RR; M8766 RR; M8867 RR; M8527 RR; M9350; M8866 and ENGOPA 314), all them recommended for cultivation in Tocantins State.

The soil preparation was carried out in a conventional way. The correction of soil acidity, as well as sowing fertilization, was performed according to chemical and physical analysis of soil. At experimental unit were collected samples of soil in the $0-20 \mathrm{~cm}$ depth layer, obtaining the following results: $\mathrm{pH}$ in $\mathrm{H}_{2} \mathrm{O}=4.5 ; \mathrm{M} . \mathrm{O}\left(\mathrm{g} . \mathrm{dm}^{-3}\right)=2.2 ; \mathrm{P}$ $\left(\right.$ Melich $\left.^{-1}\right)=1.1 \mathrm{mg} . \mathrm{dm}^{-3} ; \mathrm{Ca}=1.5 \mathrm{cmol}_{\mathrm{c}} \cdot \mathrm{dm}^{-3} ; \mathrm{Mg}=$ $0.9 \mathrm{cmol}_{\mathrm{c}} \cdot \mathrm{dm}^{-3} ; \mathrm{H}+\mathrm{Al}=2.75 \mathrm{cmol}_{\mathrm{c}} \cdot \mathrm{dm}^{-3} ; \mathrm{K}=0.31$ $\mathrm{cmol}_{\mathrm{c}} . \mathrm{dm}^{-3} ; 66 \%$ of sand; $7.5 \%$ of silt and $26.5 \%$ of clay. 
For simulation of environments of low and high levels of phosphorus, were used the doses 40 and $120 \mathrm{~kg} \mathrm{ha}^{-1}$ of $\mathrm{P}_{2} \mathrm{O}_{5}$ in the form of Triple Superphosphate $\left(37 \% \mathrm{P}_{2} \mathrm{O}_{5}\right)$, applied in the sowing row. According to Neto ${ }^{5}$, these two contrasting doses of phosphorus allowed, in experiments under Cerrado soil, the discernment of soybean cultivars regarding the grain productivity.

The experimental design was randomized blocks with three replications. The experimental plot was constituted by four rows of $5.0 \mathrm{~m}$ length, spaced by $0.45 \mathrm{~m}$. In harvest, $0.50 \mathrm{~m}$ of the end of each central row were despised. The useful area of plot was represented by the two central rows that constitute $3.6 \mathrm{~m}^{2}$.

The sowing density was performed aiming to obtain 14 plants per linear meter. In plots that the number of plants was superior to the desired, it was realized thinning at 10 days after emergence. The plants were harvested a week after showing $95 \%$ of mature pods.

Based on the useful area of plot, the following agricultural characteristics of the cultivars were evaluated: number of pods per plant (NPP), determined by manual counting of pods contained in a plant, repeating the process in 10 random plants, with subsequent achievement of an average number for that characteristic; and grain productivity (PROD), obtained by weighing of threshed grains, in $\mathrm{kg} \mathrm{plot}^{-1}$, corrected to $13 \%$ of humidity and subsequently the values were converted to $\mathrm{kg} \mathrm{ha}^{-1}$.

After data achievement, analyses of variance for each environment were performed. The averages were grouped by Scott \& Knott test at 5\% probability. All the statistical analyses were performed through the software in Genetics and Statistics - Genes ${ }^{14}$.

The characterization of cultivars regarding the fertilization use elapsed through the methodology proposed by Fageria e Kluthcouski ${ }^{8}$, in which the efficiency in the nutrient use is defined by the grain productivity average in low fertilization level. The response to the utilization of the nutrient is obtained by the difference between grain productivity in both fertilization levels, divided by the difference between doses, using the following formula: RESP $=\left(\mathrm{PROD}_{a}-\mathrm{PROD}_{b}\right) / \mathrm{DBD}$, in which $\mathrm{PROD}_{a}$ refers to grain production in high fertilization level; $\mathrm{PROD}_{\mathrm{b}}$ refers to grain production in low fertilization level; DBD refers to the difference between doses of the fertilization used.
According to Cancellier et al. ${ }^{12}$, the cultivars were dispersed in Cartesian plane for subsequent classification. On the $x$-axis is the efficiency in phosphorus use and on $y$-axis the answer to it utilization. The point of origin is the average efficiency and the cultivars average response. In the first quadrant are represented the efficient and responsive cultivars (ER); in the second, the not efficient and responsive (NER); in the third, the not efficient and not responsive (NENR) and in fourth, the efficient and not responsive (ENR). For graphical representation, it was used the computer application SigmaPlot.

\section{RESULTS AND DISCUSSION}

The coefficients of variation of variables number of pods per plant $(16.87 \%)$ and grain productivity $(7.34 \%)$ can be considered appropriate for assays of soybean cultivars under mineral stress conditions ${ }^{15}$. In this study, since joint analysis of experiments was performed, the environment of low phosphorus fertilization was the one that contributed more to raise the final value of these coefficients (Table 1). Significant difference can be verified between both environments in the characteristics assessed: in the high $P$ environment plants shown, on average, 69 pods per plant against 44 pods per plant in the low $\mathrm{P}$ environment (increase of $56.8 \%$ ). The grain productivity was also influenced positively with the elevation on phosphorus fertilization: in the high $\mathrm{P}$ environment plants shown average grain productivity of 2308.14 $\mathrm{kg} \cdot \mathrm{ha}^{-1}$, while in low $\mathrm{P}$ the production did not overcome $1549.33 \mathrm{~kg} \cdot \mathrm{ha}^{-1}$ (increase of $48.9 \%$ ). These results are superior to those reported by Brevilieri et al. ${ }^{16}$, who, with high $\mathrm{P}$ levels, observed increases of $7 \%$ on number of pods per plant and $17.8 \%$ on soy grain productivity from fertilizations with $120 \mathrm{~kg} \mathrm{ha}^{-1}$ of $\mathrm{P}_{2} \mathrm{O}_{5}$ in Cerrado soils. Neto et al. ${ }^{5}$ also found significant effect in the productivity of soy genotypes in Cerrado soils in function of a raise on fertilization levels, with increase of $30.7 \%$ in grain productivity, with fertilization levels similar to the used in this study.

In relation to the number of pods per plant (NPP), in high P environment, cultivars M8766 RR and P99R01 shown the highest averages with 100 and 98 pods, respectively, do not differing significantly of the other six cultivars. However, in low $\mathrm{P}$ environment, stand out the cultivars JULIANA RR, M9144 RR and M8766 RR, with 69, 64 and 62 pods, respectively. 
Table 1. Number of pods per plant and soy grains productivity in Cerrado soils under different conditions of phosphorus fertilization, crop 2013/2014, Gurupi-TO.

\begin{tabular}{|c|c|c|c|c|c|c|c|c|c|c|c|c|}
\hline \multirow{3}{*}{$\begin{array}{l}\text { Cultivars } \\
\text { P98Y51 }\end{array}$} & \multicolumn{5}{|c|}{ NPP } & \multicolumn{7}{|c|}{ PROD $\left(\mathrm{kg} \mathrm{ha}^{-1}\right)$} \\
\hline & \multicolumn{2}{|c|}{ High P } & Low $\mathrm{P}$ & \multicolumn{2}{|c|}{ Mean } & \multicolumn{3}{|c|}{ High P } & \multicolumn{3}{|c|}{ Low $P$} & Mean \\
\hline & 73 & a $A$ & 27 b B & 50 & b & 2446.67 & $a$ & A & 1416.30 & $b$ & B & 1931.48 \\
\hline P98Y70 & 58 & b A & $34 \mathrm{~b} A$ & 46 & $b$ & 2240.74 & $b$ & A & 1472.22 & $b$ & B & 1856.48 \\
\hline P99R01 & 98 & a $A$ & 56 b $B$ & 77 & a & 2513.33 & $a$ & A & 1725.19 & a & B & 2119.26 \\
\hline P99R03 & 59 & b $A$ & $43 \mathrm{~b} \mathrm{~A}$ & 51 & $b$ & 2126.67 & $b$ & A & 1645.81 & $a$ & B & 1884.26 \\
\hline P98R91 & 74 & a $A$ & 47 b B & 61 & a & 2455.93 & $a$ & A & 1745.19 & $a$ & B & 2100.56 \\
\hline JULIANA RR & 80 & a $A$ & 69 a $A$ & 75 & a & 2305.68 & $\mathrm{a}$ & A & 1546.67 & $b$ & B & 1926.18 \\
\hline STS 820 RR & 68 & a $\mathrm{A}$ & 32 b $B$ & 50 & b & 2168.15 & $b$ & A & 1564.44 & $b$ & B & 1866.30 \\
\hline M9056 RR & 39 & b A & $37 \mathrm{~b} A$ & 38 & b & 2394.56 & $a$ & A & 1606.30 & $\mathrm{a}$ & B & 2000.43 \\
\hline M9144 RR & 88 & a $A$ & 62 a $A$ & 75 & a & 2882.22 & $a$ & A & 1655.19 & $a$ & B & 2268.71 \\
\hline M8766 RR & 100 & a $A$ & 64 a B & 82 & a & 2216.30 & $b$ & A & 1506.30 & $b$ & B & 1861.30 \\
\hline M8867 RR & 52 & b $A$ & $30 \mathrm{~b} A$ & 44 & b & 2068.89 & $b$ & A & 1331.11 & $b$ & B & 1700.00 \\
\hline M8527 RR & 51 & b $A$ & $24 \mathrm{~b} A$ & 37 & b & 2373.33 & $b$ & A & 1366.67 & $b$ & B & 1870.00 \\
\hline M9350 & 50 & b $A$ & $36 \mathrm{~b} A$ & 43 & b & 2281.48 & $b$ & A & 1469.63 & $b$ & B & 1875.56 \\
\hline M8866 & 82 & a $A$ & 49 b B & 65 & a & 2066.67 & $b$ & A & 1601.48 & $a$ & B & 1834.07 \\
\hline ENGOPA 314 & 62 & b $A$ & $48 \mathrm{~b} A$ & 55 & a & 2081.48 & $b$ & A & 1587.41 & $a$ & $\mathrm{~B}$ & 1834.44 \\
\hline Mean & 69 & $A$ & $44 \quad B$ & & & 2308.14 & & A & 1549.33 & & B & \\
\hline CV (\%) & & 5.43 & 18.52 & 16 & & 6.22 & & & 8.25 & & & 7.34 \\
\hline
\end{tabular}

Note. Means followed by same lowercase letters in columns and uppercase in lines constitute statistically homogeneous group, by Scott and Knott test at 5\% probability. High P: $120 \mathrm{~kg} \mathrm{ha}^{-1}$ of $\mathrm{P}_{2} \mathrm{O}_{5}$; Low P: $40 \mathrm{~kg} \mathrm{ha}^{-1}$ of $\mathrm{P}_{2} \mathrm{O}_{5}$.

Being pods strong drains of phosphorus in soy plants: more than $50 \%$ of aerial part phosphorus are translocated for formation and filling of pods, Rosolem e Tavares ${ }^{17}$, studying symptoms of phosphorus (P) deficiency in soy, verified that the nutritional stress harmed the formation of pods and that the soybean plants were sensitive to the phosphorus deficiency, with an increase on the percentage of pods abscission when the deficiency presented itself in postflowering stage.

In relation to grain productivity (PROD) in high $P$, the cultivars P98Y70, P99R01, P98R91, JULIANA RR, M 9156 RR and M9144 RR stood out, composing a statistically group of the highest averages. In low $\mathrm{P}$ environment the cultivars P99R01, P99R03, P98R91, M9056 RR, M9144 RR, M8866 and ENGOPA 314 remained grouped in same statistically group, with the highest averages.

It is also observed that, regardless of the environment, the cultivars that shown the highest averages of PROD were not necessarily the ones with the highest averages of NPP. According to Peixoto et al. ${ }^{18}$, this characteristic is not sufficient to guarantee that the productivity potential will be reached, since it depends on the capacity of plant to fill the pods with grains. Rosolem e Tavares ${ }^{17}$, in soybean experiment in different conditions of phosphorus fertilization, verified that in deficient plants, the higher the demand for the nutrient to pod formation, the higher the percentage of grains with deficient maturation, while in plants with lower NPP the few pods formed were better nourished, with higher grain weight.

The cultivars M8766 RR and M8867 RR were classified as not efficient in phosphorus use and not responsive to its utilization - NENR, by presenting grain productivity lower than the overall average of genotypes in environments of low and high $P$, expressed, thus, in the first quadrant of Figure 1. Cultivars classified this way are not recommended to be sown in agricultural properties of Cerrado areas, regardless of the fertilization level used, since, in low levels of phosphorus fertilization, they are not very productive, with small productivity increases when cultivated under high investment in fertilizers. 
Figure 1. Efficiency in use of phosphorus and response to its utilization in soybean cultivars, by methodology of Fageria \& Kluthcouski (1980), crop 2013/2014, Gurupi-TO.

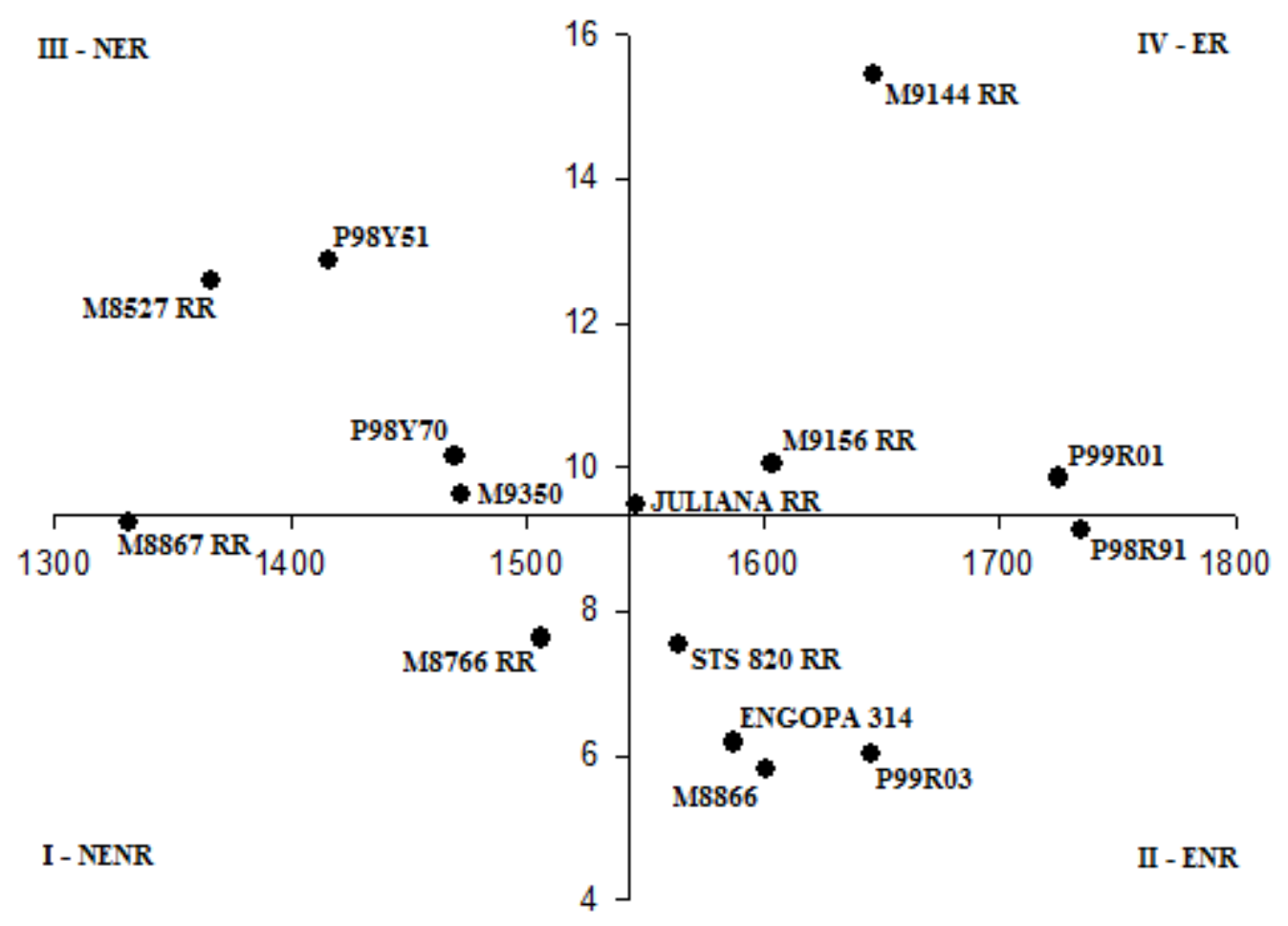

Font: Authors

The cultivars STS 820 RR, ENGOPA 314, M8866, P99R03 and P98R91 were classified as efficient in phosphorus use and not responsive to its utilization - ENR, which produced above average in low phosphorus environment (1549.33 kg.ha $\left.{ }^{-1}\right)$. However, when cultivated in high level of phosphorus environment, they had values of response rates smaller than the overall average (9.4), expressed, thus, in the second quadrant of Figure 1. Cultivars classified this way are recommended for cultivation in properties that adopt low technology, as a strategy for a satisfactory grain production in unfavorable environments, with small financial outlay in the supplementation of the phosphorus levels of soil.

According to Calderón ${ }^{19}$, efficient plants in phosphorus use have genes that confer adaptive mechanisms to contour low availability of nutrients in the environment, among them modifications in architecture and growth of the root, increase in phosphatase production and change in the activity of several enzymes in glycolytic route. Nevertheless, in presence of appropriate nutritional levels, these genes may not express themselves, resulting in a lower plant response to the environmental improvement.

Phosphorus is an element of low mobility in soil, so its absorption by plants is directly related to the root system of genotypes. As reported by Procópio et al. $^{20}$, differences between plants in relation to efficiency in the use of the nutrient can be assigned to the fact that the absorption of the phosphorus present in the soil solution occurs via root interception, so that plants of bigger root system present advantages in its capture.

The cultivars M8527 RR, P98Y51, M9350 and P98Y70 were classified as not efficient in phosphorus use and responsive to its utilization NER, because they produced below average of the genotypes in low $\mathrm{P}$ environment, with production of $1366.67 ; 1416.30 ; 1465.63$ and $1472.22 \mathrm{~kg} \mathrm{ha}^{-1}$, respectively. However, when cultivated in high $\mathrm{P}$ environment, they presented response rates above average of the others genotypes and, thus, are expressed in the third quadrant of Figure 1. Cultivars classified this way are recommended for sowing in high technology, because they answer to 
the environment improvement by the increase in the phosphorus fertilization.

The cultivars JULIANA RR, M9156 RR, P99R01 and M9144 RR were classified as efficient in phosphorus use and responsive to its utilization $E R$, by presenting grain productivity superior to overall average of genotypes in low and high $P$ environments, expressed, thus, in the fourth quadrant of Figure 1. For each kilogram of phosphorus added, the cultivars increased in 9.48; 9.86; 9.85; and $15.34 \mathrm{~kg} \mathrm{ha}^{-1}$, respectively, the grain production. Cultivars classified this way are recommended for cultivation in different levels of phosphorus fertilization, showing themselves productive in environments of lower fertility, besides answering to the investment in phosphorus fertilization.

The dynamics of phosphorus in soil-plant interaction, of close relation with the edaphoclimatic conditions, is also correlated to arbuscular mycorrhizal fungi, naturally present in Cerrado soils and affected by management and fertility of them ${ }^{21}$. These fungi have essential role in ecosystems, benefiting plants by the increase of nutrients absorption ${ }^{22}$. The interaction between fungus and plant varies according to the genotype, since they have affinity for root systems with characteristics that favor mycorrhizal symbiosis, like higher exudation of lipids, carbohydrates and carbon compounds ${ }^{23}$. The effect of $P$ on the efficiency of mycorrhizal fungi in dry matter and grains production has been verified by many authors, in several situations ${ }^{24,25}$. These studies shown that low doses of $\mathrm{P}$ increase mycorrhization and efficiency of mycorrhizal fungi in promoting dry matter increase; however, high doses of this nutrient affect negatively the mycorrhization. The efficient cultivars in phosphorus use can be related to higher levels of mycorrizal interaction and consequent increase in nutrient absorption.
It is important highlight that cultivars JULIANA RR, M9056 RR, P99R01 and M9144 RR, classified as efficient to phosphorus use and responsive to its utilization, are from different groups of physiological maturity. According to Peluzio et al. ${ }^{26}$ and Santos et al. ${ }^{27}$, in evaluations of soybean genotypes in southern Tocantins state, the cultivars M9144 RR and M9056 RR are classified as late maturation cycle, while the cultivars P99R01 and JULIANA RR present average maturation cycle. Thus, excludes itself the tendency of only late cycle genotype be superior in unfavorable environmental conditions, by its ability to develop, throughout the vegetative stage, mechanisms of tolerance to stress $^{28}$.

\section{CONCLUSIONS}

The cultivars JULIANA RR, M9056 RR, P99R01 and M9144 RR are efficient in phosphorus use and responsive to its utilization, and thus recommended for cultivation in Cerrado soils of Tocantins, regardless of the condition of phosphorus fertilization.

The cultivars STS 820 RR, ENGOPA 314, M8866, P99R03 and P98R91 are not efficient in phosphorus use and not responsive to its utilization.

\section{AUTHORS' CONTRIBUITIONS}

1 - Condução e avaliação do experimento, análises estatísticas e elaboração do artigo:

\section{Gustavo André Colombo \\ Luiz Paulo Miranda Pires \\ Gilberto Coutinho Machado Filho}

2 - Planejamento, orientação e revisão final do artigo:

Joenes Mucci Pelúzio

Douglas Daronch

\section{REFERENCES}

[1]. CEPEA, Centro de Estudos Avançados em Economia Aplicada. Relatório PibAgro Brasil 2012. Available in:

$<$ http://www.cepea.esalq.usp.br/comunicacao/Cepea PIB BR dez12.pdf>. Accessed on: 02 Mai. 2015.
[2]. CONAB, Companhia Nacional de Abastecimento. Acompanhamento de safra brasileira: grãos, décimo levantamento, julho 2015. Available in:

$<$ http://www.agricultura.gov.br/arq editor/10\%20LE VANTAMENTO\%20CONAB.pdf $>$. Accessed on: 22 jul. 2015.

[3]. OECD, Countries and Emerging Economies. Agricultural Policy Monitoring and Evaluation 
2012. OECD Publishing, Paris, 2012. 288p. Available in:

<http://dx.doi.org/10.1787/agr pol-2012-en>. Accessed on: 02 Mai. 2015

[4]. WATANABE, R.T.; FIORETTO, R.A.; FONSECA, I.B.; SEIFERT, A.L.; SANTIAGO, D. C.; CRESTE, J.E.; HARADA, A.; CUCOLOTTO, M. Soybean yield under different density of populations and cations percentage ( $\mathrm{Ca}, \mathrm{Mg}$ and $\mathrm{K}$ ) in base saturation. Semina: Ciências Agrárias, v.26, n.4, p.477-484, 2005.

[5]. NETO, F.A.; GRAVINA, G.A.; SOUZA, N.O.S.; BEZERRA, A.A.C. Phosphorus fertilization in the soybean crop at the micro region of Alto Médio Gurguéia. Revista Ciência Agronômica, v.41, n.2, p.266-271, 2010.

[6]. RAUSCH, C.; BUCHER, M. Molecular mechanisms of phosphate transport in plants. Planta, v.216, p.23-37, 2002.

[7]. HORN, D.; ERNANI, P.R.; SANGOI, L.; SCHWEITZER, C.; CASSOL, P.C. Parâmetros cinéticos e morfológicos da absorção de nutrientes em cultivares de milho com variabilidade genética contrastantes. Revista Brasileira de Ciência do Solo, v.30, n.1, p.77-85, 2006.

[8]. FAGERIA, N.D; KLUTHCOUSKI, J. Metodologia para avaliação de cultivares de arroz e feijão para condições adversas de solo. Brasília: Embrapa/CNPAF, 1980. 22p. (Circular Técnica, 8).

[9]. FAGERIA, N.K.; BALIGAR, V.C.; JONES, C.A. Growth and mineral nutrition of field crops. 2.ed. New York : M. Dekker, 1997. 624p.

[10]. MOLL, R.H.; KAMPRATH, E.J.; JACKSON, W.A. Analysis and interpretation of factors which contribute to efficiency of nitrogen utilization. Agronomy Journal, v.74, n.3, p.562-564, 1982.

[11]. FIDELIS, R.R.; MIRANDA, G.V.; PELÚZIO, J.M.; GALVÃO, J. C. C. Corn population classification as to efficiency and response to phosphorus use. Acta Scientiarum: Agronomy, v.32, n.2, p.241246, 2010.

[12]. CANCELLIER, E.L.; BRANDÃO, D.R.; SILVA, J.; SANTOS, M.M.D.; FIDELIS, R.R. Phosphorus use efficiency of upland rice cultivars on Cerrado soil. Ambiência, v.8, n.2, p.307-318, 2012.

[13]. OLIVEIRA, T.C.D.; SILVA, J.; SALGADO, F.H.M.; SOUSA, S. A.; FIDELIS, R. R. Efficiency and responso to phosphorus application in common bean on cerrado soils. Revista Verde de Agroecologia e Desenvolvimento Sustentável, v.7, n.1, p.16-24, 2012.
[14]. CRUZ, C.D. Programa Genes: Estatística Experimental e Matrizes. 1a Ed. Viçosa: UFV, Brasil, 2006. 285 p.

[15]. STORCK, L.; CARGNELUTTI FILHO, A.; LÚCIO, A.D.; MISSIO, E.L.; RUBIN, S.A.L. Experimental precision evaluation of soybean cultivar yield trials. Ciência e Agrotecnologia, v.34, n.3, p.572578, 2010.

[16]. BREVILIERI, R.C. Adubação fosfatada na cultura da soja em Latossolo vermelho cultivado há 16 anos sob diferentes sistemas de manejo. 2012, 52f. Dissertação mestrado da Universidade Estadual De Mato Grosso do Sul. AquidauanaMS.

[17]. ROSOlEM, C.A.; TAVARES, C.A. Phosphorus deficiency symptoms in soybean. Revista Brasileira de Ciência do Solo, v.30, n.2, p.385389, 2006.

[18]. PEIXOTO, C.P.; CÂMARA, G.M.S.; MARTINS, M.C.; MARCHIORI, L.F.S. Efeito de épocas de semeadura e densidades de plantas sobre o rendimento de cultivares de soja no estado de São Paulo.Revista de Agricultura, Piracicaba-SP, v.77, n.2, p.265-293, 2002.

[19]. CALDERÓN, L.S. Genetic characterization of morpho-physiological responses of the root system of Arabidopsis thaliana (L.) Heynh., for phosphorus deficiency. (PhD Thesis). Ciudad de México: Centro de Investigación y de Estudios Avanzados del Instituto Politécnico Nacional CINVESTAV, 2006.

[20]. PROCÓPIO, S.O.; SANTOS, J.B.; PIRES, F.R.; SILVA, A.A.; MENDONÇA, E.S. Absorption and utilization of phosphorus by soybean and bean and weeds. Revista Brasileira de Ciências do Solo, v.29, p.911-921, 2005

[21]. LOSS, A.; ANGELINI, G.A.R.; PEREIRA, A.C.C.; LÃ, O.R.; MAGALHÃES, M.O.L.; SILVA, E.M.R.; SAGGIN JUNIOR, O.J. Chemical attributes of soil and occurrence of mycorrhizal fungi under areas of pasture and agroforest system, Brazil. Acta Agronómica, v.58, n.2, p.91-95, 2009.

[22]. BERBARA, R.L.L.; SOUZA, F.A.; FONSECA, H.M.A.C. Fungos Micorrízicos arbusculares: muito além da nutrição. In: FERNANDES, M.S. (Ed.). Nutrição mineral de plantas. Viçosa, MG: Sociedade Brasileira de Ciência do Solo, 2006. p. 53-88.

[23]. PRINGLE, A.; BEVER, J.D.; GARDES, M.; PARRENT, J.L.; RILLIG, M.C.; KLIRONOMOS, J.N. Mycorrhizal symbioses and plant invasions. Annual Review of Ecology, Evolution, and Systematics, v.40, p.699-715, 2009. 
[24]. SMITH, S.E.; JAKOBSEN, I.; GRONLUND, M.; SMITH, F. A. Roles of arbuscular mycorrhizas in plant phosphorus nutrition: interactions between pathways of phosphorus uptake in arbuscular mycorrhizal roots have important implications for understanding and manipulating plant phosphorus acquisition. Plant Physiology, v.156, n.3, p.1050-1057, 2011.

[25]. ANGELINI, G.A.R.; LOSS, A.; PEREIRA, M.G.; TORRES, J.L.R.; JÚNIOR, O.J.S. Mycorrhizal colonization, spore density and diversity of arbuscular mycorrhizal fungi in Cerrado soil under no-till and conventional tillage systems. Semina: Ciências Agrárias, v.33, n.1, p.115-130, 2012.

[26]. PELUZIO, J.M.; VAZ-DE-MELO, A.; COLOMBO, G.A.; SILVA, R.R.; AFÉRRI, F.S.; PIRES, L.P.M.;
BARROS, H.B. Effect of edaphoclimatic changes in South-Central region of the state of Tocantins on grain yield of soybean cultivars. Pesquisa Aplicada \& Agrotecnologia, v.3, p.145-153, 2010.

[27]. SANTOS, E.R.; BARROS, H.B.; FERRAZ, E.C.; CELLA, A.J.S.; SANTOS, A.F.; FIDELIS, R.R. Divergence between soybean genotypes grown in irrigated lowland, Brazil. Revista Ceres, v.58, n.2, p.755-764, 2011.

[28]. ALLIPRANDINI, L.F.; ABATTI, C.; BERTAGNOLLI, P.F.; CAVASSIM, J.E.; GABE, H.L.; KUREK, A.; STECKLING, C. Understanding soybean maturity groups in Brazil: environment, cultivar classification, and stability. Crop Science, v.49, n.3, p.801-808, 2009. 